\title{
How globalization affects the operational efficiency of emerging market firms?: A comparative analysis on Turkish SMEs
}

\author{
Ece Ceylan Akdoğan* \\ Çankaya University, Turkey
}

Received: 26 November 2017

Revised: 20 March 2018

Accepted: 21 March 2018

\begin{abstract}
This paper examines the impact of globalization on the operational efficiency of emerging market firms by concentrating on the financial outcomes of a firm's main operations through focusing on operating income and cash conversion cycle as well as on their possible causes in an emerging market, Turkey. The findings indicate that globalization significantly deteriorates the operating income and lengthens the cash conversion cycle of Turkish firms. Besides, globalization is found to increase sales of SMEs and decrease sales of large companies significantly and the impact on operating income of large companies is observed to be stronger. Globalization is also found to lead a softening in Turkish firm's terms of sales and enable Turkish SMEs to benefit from better terms of purchase.
\end{abstract}

Keywords: globalization; operational efficiency; working capital; SME; emerging markets JEL Classification Codes: C23, F18, F61, M21

\section{Introduction}

In the last few decades, the world has gone through a process of increasing interconnectedness and interdependence among nations in all aspects of life and through its widespread influences, Ardiç (2009) argues that although the term 'globalization' is used to refer to a single phenomenon, it is not a single, unified process. Rather, it covers a wide range of distinct political, economic, and cultural trends (Scheuerman 2010). Thus, there is no unified definition of globalization as well. Indeed, as Kefela (2011) deems globalization continues to mean very different things to different people. Just to mention a few, Szeman (2003) defines globalization as the moment of mass migration, multiculturalism, and cosmopolitanism while Giddens (1990) defines globalization as the intensification of world-wide social relations which link distant localities in such a way that local happenings are shaped by events occurring many miles away and

\footnotetext{
*E-mail: ece@cankaya.edu.tr.

Citation: Akdoğan, E. C. (2018) How Globalization Affects the Operational Efficiency of Emerging Market Firms?: A Comparative Analysis on Turkish SMEs, Economics and Business Letters, 7(1), 9-17.
} 
vice versa. According to International Forum on Globalization, it stands for the present worldwide drive toward a globalized economic system dominated by supranational corporate trade and banking institutions that are not accountable to democratic processes or national governments.

In line with its extensively wide scope, the process of globalization has been extensively researched from a wide spectrum as well. However, the previous literature mainly focus on the macro side effects of globalization through concentrating on national economic factors (Dreher 2006, Rao et al. 2011), entrepreneurship (Vining and De Kluijver 2007), life satisfaction (Hessami 2011) and human welfare (Tsai 2007), unionization (Dreher and Gaston 2007), political (Leibrecht et al. 2011) and environmental issues (Lamla 2009), military interstate disputes (Choi 2010) etc., or nest the productivity and pass-through literatures spanning industrial organization, international trade, and international macro (De Loecker and Goldberg 2014) with a dearth on the ultimate financial outcomes of firm level effects. Among the highly limited past empirical research in the finance literature, Acheampong et al. (2004) examined the profitability adjustment patterns of global firms and tested whether globalization equalizes speeds of profitability adjustment. Their findings suggest no significant country effect in beverage and tobacco industry while in food and consumer products industry, speeds of profitability adjustment is found to vary across countries. Focusing on US companies, Asiedu and Freeman (2007) report that globalization negatively affects the profitability of the minority-owned firms with no significant affect for the white-owned firms. The results of Peltonen et al. (2008) indicate that import competition from emerging market economies deteriorates firm profitability in the euro area manufacturing sector. In contrast, Georgiou (2011) reports a positive impact of globalization on company profitability for Europe. Through focusing on Nigerian Banks, Akinola (2012) found that profit before tax is positively influenced by globalization. The findings of Karadagli (2012) suggest that firm performance as measured by the return on stock market indices increases with globalization for Emerging 7 Countries; The results of Donadelli and Prosperi (2012) indicate that financial and real market openness increase, ex-post, expected excess returns in emerging stock markets; and the results of Haghi et al. (2015) show that economic globalization significantly improves stock market index. However, although Karadagli (2013) reports a positive impact of globalization on the stock returns, detects a negative impact on operating income. In their study, Thoumrungroje and Tansuhaj (2007) also concluded that globalization acts as a two-edged sword that can be both beneficial and detrimental to businesses. In a recent study, Mahmutovic et al. (2017) have confirmed earlier findings about the double impact of globalization by showing its positive effects on the one hand, and the negative effects on the other, on the performance of the companies.

Given the dearth of past empirical evidence and the contradictory results obtained, how globalization actually affects firms still stays as a puzzle to be solved. Consequently, this research aims to investigate the impact of globalization ${ }^{1}$ on the operational efficiencies of emerging market firms by concentrating on Turkish companies. For that purpose, it mainly focuses on the question of how globalization affects the financial outcomes of a firm's main operations in an emerging market setting. Although the operational efficiency is the concern of all firms, since liquidity burden is among the most prominent obstacles faced by emerging market firms, it can

\footnotetext{
${ }^{1}$ Within the scope of this study, globalization refers to the overall dynamics arising from economic, political and social dimensions of globalization, each of which have important consequences in shaping the international business environment through providing new opportunities and exposing new threats. Political dimension of globalization mainly reflects the degree of political interrelations across the globe while social dimension of globalization is based on the spread of ideas, information, images and people. Following the globalization definition of De and Pal (2011), economic globalization is referred as the process of opening up of economies to the outside world to facilitate trade, reduction in physical and other barriers to increase mobility of goods and factors of production.
} 
be argued to be more vital for them. Since the assets of most SMEs are in the form of current assets (Garcia-Teruel and Martinez-Solano 2007) and as they have fewer alternative sources of external finance available which make them more dependent on short term finance in general and trade credit in particular (Falope and Ajilore 2009), they will be more vulnerable to working capital fluctuations (Padachi 2006). Considering that firm size is generally argued to impact the affects of globalization on firm performance (Hsu and Chen 2000), this study is also aimed at searching for any potential differences that may prevail between SMEs and large companies. Such a distinction is important for several reasons. First of all, SMEs, in general, have comparatively limited access to capital markets causing them to operate under a capital burden and leading them to rely more heavily on internally generated funds and short term finance. Correspondingly their investment capabilities are relatively weaker and production capacities of their assets, sales volumes and market shares are generally limited. Likewise, their negotiation powers within the supply chains and in marketing activities are lower. Besides, the division of tasks is generally not well-defined in SMEs preventing specialization and they usually have deficiencies in financial planning. On the other hand, they often have a more dynamic structure and are more flexible in adopting technological innovations and inventions. Last but not least they generally have closer relationships with their customers. Such distinguishing features of SMEs require a special focus. But despite the fact that globalization has transformed the supply and demand conditions across the globe (Tomschik 2015), the overall effect of competition on the performance of SMEs is unclear (Asiedu and Freeman 2007) as well. However, since they are usually accepted as the driving forces of emerging economies, a deeper understanding of how globalization actually affects the performances of SMEs, especially in emerging markets, proves to be another critical question. Thus, through seeking answers to the abovementioned questions, the main motivation of this research is to explore the firm level effects of globalization through focusing on the operational efficiency concerns in an emerging market context.

\section{Methods}

Following the aforementioned arguments, the research is designed to investigate the impact of globalization on the operating income and cash conversion cycle of Turkish firms as well as their possible causes and to search for any potential differences that may prevail between SMEs and large companies. The sample consists of 142 Turkish listed companies among which 56 of them are SMEs ${ }^{2}$ according to EU definition. The impact of globalization on the operational efficiency of Turkish listed companies are searched for the period of 2001-2010 by using pooled panel analysis with annual data through concentrating on the financial outcomes of firm's operational activities. For this purpose, several dependent variables are employed, specifically operating income (OpInc), sales, cost of goods sold (COGS), cash conversion cycle (CCC $)^{3}$, average collection period (ACP), days in inventory (DiI) and average payback period (APP) while firm size, financial leverage and GDP growth rate are used as control variables along with a dummy variable to account for industrial effects, leaving us with the seven versions of the below model:

\footnotetext{
${ }^{2}$ Although the EU definition of a SME is not well-suited to the Turkish economy since those criteria are considerably over scaled for a typical Turkish SME, it still serves as a good proxy due to lack of data combined with the reluctance of typical Turkish SMEs in sharing their financial information. However, any potential difference encountered based on this distinction can still provide a valuable benchmark in the sense that any cause of such a distinction can be expected to be stronger for a typical Turkish SME.

${ }^{3}$ Considering that globalization has not only altered the worldwide demand and supply conditions as well as the market shares and competitiveness of firms but also impact their negotiation powers and enable diversifying operations (sales, inputs and production) and financing, globalization is expected to potentially affect the CCC and its components, specifically ARP, DiI and APP.
} 


$$
Y_{i, t}=\beta_{0}+\beta_{1} G_{t}+\beta_{2} S_{i, t}+\beta_{3} F L_{i, t}+\beta_{4} G D P g r_{t}+\beta_{5} D_{\text {ind }}+\varepsilon
$$

where Y, G, S, FL and Dind denote dependent variable (specifically natural logarithms of operating income, sales and COGS as well as CCC, ACP, DiI and APP), globalization index, firm size, financial leverage and industry dummy respectively.

Then, the whole sample is divided into two subsamples, specifically the SMEs and the large companies, and the first seven models are duplicated by subdividing the globalization index (G) variable accordingly to search for any prevailing differences which brings in the additional seven versions of the below model:

$$
Y_{i, t}=\beta_{0}+\beta_{1} G_{S M E t}+\beta_{2} G_{L C t}+\beta_{3} D_{S M E}+\beta_{4} S_{i, t}+\beta_{5} F L_{i, t}+\beta_{6} G D P g r_{t}+\beta_{7} D_{\text {ind }}+\varepsilon
$$

As seven independent variables are used for both Eq. (1) and Eq. (2), finally 14 models are reached.

\section{Data}

CCC which refers to the length of time from the payment for the purchase of raw materials to manufacture a product until the collection of account receivable associated with the sale of the product (Besley and Brigham 2005) is calculated by adding the ACP with DiI and subtracting the APP where ACP, DiI and APP are computed by multiplying the division of accounts receivables to sales with 365 , multiplying the division of inventory to COGS with 365 and multiplying the division of accounts payables to COGS with 365, respectively. To control for firm size, natural logarithm of total assets is used. Financial debt ratio which is calculated by dividing the sum of short and long term borrowing to total assets is used as a proxy for financial leverage and GDP growth rate is used to control for fluctuations in the national economic conjuncture. To control for the industry effects, two-digit industry codes are assigned to firms based on industry classification of Borsa Istanbul.

All the financial data of companies are extracted from Bloomberg, GDP growth rate is sourced from IMF database and Turkish globalization index is obtained from KOF Index of Globalization which was developed by Dreher (2006), updated by Dreher et al. (2008) and provided by Swiss Federal Institute of Technology, Zurich.

KOF Index of Globalization is a highly comprehensive composite index combining the relevant data on three dimensions that are based on economic, political and social factors. The economic dimension of globalization consists of both the actual flows (specifically trade, foreign direct investment, portfolio investment and income payments to foreign nationals) and the restrictions (specifically hidden import barriers, mean tariff rate, taxes on international trade as a percentage of current revenue and capital account restrictions). Political dimension of globalization covers the variables of number of embassies in country, number of membership in international organizations, number of UN peace missions she participated in and number of treaties she signed with other nations while social dimension of globalization is based on the spread of ideas, information, images and people by combining data on personal contacts, information flows and cultural proximity. A more detailed explanation of how KOF Indices of Globalization are constructed is provided at the website of Swiss Federal Institute of Technology.

\section{Results}

The results obtained from the pooled panel analysis of the above models for the whole sample (Models 1-7) are provided in Table 1. 
Table 1. Panel analysis results for the whole sample.

\begin{tabular}{|c|c|c|c|c|c|c|c|}
\hline & $\begin{array}{c}\text { Model } 1 \\
\text { (OpInc) }\end{array}$ & $\begin{array}{r}\text { Model } 2 \\
\text { (Sales) }\end{array}$ & $\begin{array}{l}\text { Model } 3 \\
(\text { COGS) }\end{array}$ & $\begin{array}{r}\text { Model } 4 \\
(\text { CCC })\end{array}$ & $\begin{array}{r}\text { Model } 5 \\
(A C P)\end{array}$ & $\begin{array}{r}\text { Model } 6 \\
(\text { DiI) }\end{array}$ & $\begin{array}{r}\text { Model } 7 \\
(A P P)\end{array}$ \\
\hline \multirow[t]{2}{*}{$G$} & $-0.0376^{* * *}$ & $-0.0021 *$ & $-0.0069 * * *$ & $2.6356 * * *$ & $1.8242 * * *$ & $1.6879 * * *$ & $0.8757 * * *$ \\
\hline & $(-17.0707)$ & $(-1.7338)$ & $(-4.7422)$ & $(7.2556)$ & (7.9308) & $(8.9308)$ & $(9.7401)$ \\
\hline \multirow[t]{2}{*}{$S$} & $1.0148 * * *$ & $1.0003 * * *$ & $1.0182 * * *$ & $-13.4584 * * *$ & $-6.8555 * * *$ & $-8.8259 * * *$ & $-2.2395 * *$ \\
\hline & (42.6584) & (74.7982) & $(65.6995)$ & $(-3.4929)$ & $(-2.7136)$ & $(-4.4036)$ & $(-2.3481)$ \\
\hline \multirow[t]{2}{*}{$F L$} & $-0.4237 * *$ & 0.1172 & 0.11572 & 30.2877 & 1.6506 & $59.1125 * * *$ & $30.1072 * * *$ \\
\hline & $(-2.3890)$ & (1.1966) & $(1.3952)$ & $(1.0832)$ & $(0.0893)$ & $(4.0578)$ & (4.348) \\
\hline \multirow[t]{2}{*}{$G D P g r$} & $-0.0196 * * *$ & 0.0021 & 0.0044 & -1.2285 & $-1.5198 * *$ & -0.2906 & $-0.5789 * *$ \\
\hline & $(-3.0674)$ & $(0.5971)$ & (1.0778) & $(-1.2162)$ & $(-2.2681)$ & $(-0.5522)$ & $(-2.3147)$ \\
\hline \multirow[t]{2}{*}{ Dind } & -0.0020 & -0.0022 & $-0.0066 * *$ & -0.3324 & -0.4195 & $0.5895^{*}$ & $0.5255 * *$ \\
\hline & $(-0.5017)$ & $(-0.9922)$ & $(-2.4564)$ & $(-0.5023)$ & $(-1.0078)$ & $(1.7091)$ & $(3.2027)$ \\
\hline
\end{tabular}

Notes: t-statistics are presented in parentheses; $* * *, * *, *$ denote statistical significance at $1 \%, 5 \%$ and $10 \%$ levels, respectively.

The findings of Model 1 indicate that the operating income of Turkish firms deteriorates with globalization at 1\% significance level. As the results of Models 2 and 3 are considered, globalization is found to decrease both sales and COGS of Turkish companies with $10 \%$ and $1 \%$ significance levels respectively. On the other hand, globalization is found to significantly increase CCC and all its components at $1 \%$ significance level indicating that the combined effect of globalization on ACP and DiI dominates the shortening effect of APP on CCC. Besides, firm size is found to impact all the dependent variables at $1 \%$ significance level. So, to get a better understanding on how globalization actually affects firms, any potential difference on the impacts of globalization that may prevail between SMEs and large companies are searched and the results obtained from the pooled panel analysis for the subsamples of SMEs and large companies (Models 8-14) are summarized in Table 2.

Table 2. Panel analysis results for the subsamples of SMEs and large companies

\begin{tabular}{|c|c|c|c|c|c|c|c|}
\hline & $\begin{array}{c}\text { Model } 8 \\
(\text { OpInc })\end{array}$ & $\begin{array}{r}\text { Model } 9 \\
(\text { Sales })\end{array}$ & $\begin{array}{r}\text { Model } 10 \\
(\text { COGS }) \\
\end{array}$ & $\begin{array}{r}\text { Model } 11 \\
(C C C) \\
\end{array}$ & $\begin{array}{r}\text { Model } 12 \\
(A C P) \\
\end{array}$ & $\begin{array}{r}\text { Model } 13 \\
(\text { DiI })\end{array}$ & $\begin{array}{r}\text { Model } 14 \\
(\text { APP })\end{array}$ \\
\hline$G_{S M E}$ & $\begin{array}{r}-0.0342 * * * \\
(-11.3042)\end{array}$ & $\begin{array}{r}0.0117 * * * \\
(7.0833)\end{array}$ & $\begin{array}{r}-0.0079 * * * \\
(3.9250)\end{array}$ & $\begin{array}{r}1.4646 * * * \\
(2.6842)\end{array}$ & $\begin{array}{r}1.5146 * * * \\
(4.5926)\end{array}$ & $\begin{array}{r}0.7326 * * * \\
(2.7442)\end{array}$ & $\begin{array}{r}0.7573 * * * \\
(5.9347)\end{array}$ \\
\hline$G_{L C}$ & $\begin{array}{r}-0.0876 * * * \\
(-4.6746)\end{array}$ & $\begin{array}{r}-0.0319 * * * \\
(-3.3611)\end{array}$ & $\begin{array}{r}-0.0155 \\
(-1.4095)\end{array}$ & $\begin{array}{r}7.5914 * * * \\
(2.6841)\end{array}$ & $\begin{array}{l}3.2894 * \\
(1.7420)\end{array}$ & $\begin{array}{r}3.6703 * * \\
(2.5060)\end{array}$ & $\begin{array}{r}-0.5171 \\
(-0.7367)\end{array}$ \\
\hline$D_{S M E}$ & $\begin{array}{r}3.4422 * * * \\
(-2.7527)\end{array}$ & $\begin{array}{r}2.3512 * * * \\
(3.7032)\end{array}$ & $\begin{array}{r}0.9603 \\
(1.3062)\end{array}$ & $\begin{array}{r}-365.4972 * \\
(-1.4952)\end{array}$ & $\begin{array}{r}-106.7015 \\
(-0.8435)\end{array}$ & $\begin{array}{r}-158.8236 \\
(-1.6187)\end{array}$ & $\begin{array}{r}91.1897 * \\
(1.9401)\end{array}$ \\
\hline$S$ & $\begin{array}{r}0.9853 * * * \\
(31.1972)\end{array}$ & $\begin{array}{r}0.8655 * * * \\
(49.8422)\end{array}$ & $\begin{array}{r}0.8739 * * * \\
(42.6402)\end{array}$ & $\begin{array}{r}-2.4325 \\
(-0.4609)\end{array}$ & $\begin{array}{r}-3.9103 \\
(-1.1301)\end{array}$ & $\begin{array}{r}0.3623 \\
(0.1325)\end{array}$ & $\begin{array}{r}-0.9502 \\
(-0.7266)\end{array}$ \\
\hline$F L$ & $\begin{array}{r}-0.4063 * * \\
(-2.2587)\end{array}$ & $\begin{array}{r}0.2117 * * \\
(2.2532)\end{array}$ & $\begin{array}{r}0.2687 * * \\
(2.4509)\end{array}$ & $\begin{array}{c}26.3478 \\
(0.9356)\end{array}$ & $\begin{array}{r}0.3540 \\
(0.0189)\end{array}$ & $\begin{array}{r}53.6566 * * * \\
(3.6764)\end{array}$ & $\begin{array}{r}27.6670 * * * \\
(3.9528)\end{array}$ \\
\hline GDPgr & $\begin{array}{r}-0.0192 * * * \\
(-3.0076)\end{array}$ & $\begin{array}{r}0.0035 \\
(1.0398)\end{array}$ & $\begin{array}{r}0.0060 \\
(1.5177)\end{array}$ & $\begin{array}{r}-1.3088 \\
(-1.2994)\end{array}$ & $\begin{array}{r}-1.5394 * * \\
(-2.2933)\end{array}$ & $\begin{array}{r}-0.3818 \\
(-0.7313)\end{array}$ & $\begin{array}{r}-0.6122 * * \\
(-2.4463)\end{array}$ \\
\hline Dind & $\begin{array}{r}-0.0030 \\
(-0.7615)\end{array}$ & $\begin{array}{r}-0.0030 \\
(-1.4210)\end{array}$ & $\begin{array}{r}-0.0080 * * * \\
(-3.0955)\end{array}$ & $\begin{array}{r}-0.1408 \\
(-0.2130)\end{array}$ & $\begin{array}{r}-0.3903 \\
(-0.9356)\end{array}$ & $\begin{array}{r}0.7111 * * \\
(2.0748)\end{array}$ & $\begin{array}{r}0.5133 * * * \\
(3.1218)\end{array}$ \\
\hline
\end{tabular}

Notes: t-statistics are presented in parentheses; $* * *, * *, *$ denote statistical significance at $1 \%, 5 \%$ and $10 \%$ levels, respectively.

As the results given in Table 2 are examined, globalization has statistically significant adverse impact on operating income of both SMEs and large companies at 1\% significance level. However, with regard to the impact of globalization on sales, the findings provide contradictory results for SMEs and large companies. While sales of SMEs are found to increase, sales of large companies decrease with globalization at $1 \%$ significance levels. So, the significant adverse 
impact of globalization on sales of Turkish firms reported by the results of Model 2 conducted for the whole sample actually reflects the dominance large companies. On the other hand, although COGS of both SMEs and large companies decrease as globalization increase, this impact is found be statistically significant at $1 \%$ significance for SMEs whereas the impact on large companies is not significant at conventional levels (prob. 0.1589). When the results reported for $\mathrm{CCC}$ and its components are considered, globalization significantly increases CCC, ACP, DiI and APP of SMEs at 1\% significance level. These findings are compatible with those obtained for the whole sample. But, the findings obtained for the large companies indicate that although globalization lengthens the $\mathrm{CCC}, \mathrm{ACP}$ and DiI with $1 \%, 10 \%$ and $5 \%$ significance levels respectively, APP of large companies, though statistically not significant, seems to shorten with globalization. An overall evaluation of the results points that globalization enhances the relative competitiveness of SMEs.

\section{Concluding remarks}

Through examining the impact of globalization on the operational efficiency of Turkish firms and searching for any potential differences that may prevail between the SMEs and the large companies, this study contributes to the previous literature in several aspects. First of all, though the majority of the previous work mainly addresses the topic subject at macro level, this paper concentrates on the effects of globalization on the performance of firms operating under this business environment, by using firm level data. In this respect, given the dearth of past empirical research on the firm level effects of globalization and the contradictory results obtained, how globalization actually affects firms still stays as an important puzzle to be solved. Besides, although the operational efficiency is the concern of all firms, since liquidity burden is among the most prominent obstacles faced by emerging market firms, it can be argued to be more vital for them. Yet, to the best of our knowledge, this question has not been addressed before. On the other hand, as firm size is generally argued to impact the effects of globalization on firm performance (Hsu and Chen 2000), a deeper understanding of how globalization actually affects the performances of SMEs, especially in emerging markets, proves to be another critical question. Although globalization has altered the global demand and supply conditions, the net effect of competition on the performances of SMEs is highly ambiguous.

The findings indicate that as Turkey gets more globalized, contrary to what might be expected, the operating income of Turkish firms deteriorates. So, to get a deeper insight, the impact of globalization on sales and COGS of Turkish firms are also examined. The results point that both sales and COGS significantly decrease with globalization, probably due to increased competition. This finding provides support for Kaplinsky (2004) who deemed that despite the wide diffusion of productive capabilities to developing countries during last several decades, the growing importance of global buyers has squeezed both profit margins and incomes for developing country producers. On the other hand, when the results obtained for SMEs and large companies are considered, although the operating income of large companies is observed to be stronger, no difference could be reported on the direction of this effect. Nevertheless, the weaker adverse impact obtained for SMEs can be regarded as a partial support for Asiedu and Freeman (2007) who argue that the increased product market competition may cause SMEs to reduce their price markups or the pressure to survive may speed up the adoption of new technologies and thereby enhance the productivity of SMEs. Or, it may stem from the probability that globalization through increasing competition and dampening the operational efficiency of large home companies, may enhance the competitiveness of SMEs through reducing the pressure of the large companies in the home market accompanied with an increasing ability to expand into foreign markets. In fact, as the findings reveal sales of SMEs increase while sales of large companies decrease with globalization providing support for this argument. Globalization is also 
found to significantly increase the CCC of Turkish firms. As the components of CCC are considered, the results signify a positive impact on all the three components of CCC. This indicates that although APP of Turkish firms also increase with globalization, since the combined effect on ACP and DiI dominates the shortening effect of APP, the CCC of Turkish firms gets longer with globalization. Besides, the findings on ACP and APP also imply that globalization enables Turkish firms to benefit from better terms of purchase while they seem to soften their terms of sales. Although these results obtained for CCC and its components hold for SMEs, the findings lack to provide a statistically significant impact on APP of large companies leading to the conclusion that the components of working capital of SMEs are more sensitive to globalization. Overall, the results indicate that globalization enhances the relative competitiveness of Turkish SMEs compared to large Turkish companies.

These findings are very important for at least three reasons. First of all, SMEs and large companies should be investigated separately as the findings obtained for the combined sample may seriously be misleading. Next, it seems promising for policy makers to take this fact into account and carefully consider which group of firms they want to promote. Finally, considering that the industry dummy is found to be statistically significant for both DiI and APP as well as for COGS, these results may change considerably among sectors. Hence, future research should also focus on the industrial effects of globalization by either concentrating on a single sector or providing comparative analysis among different sectors as well.

\section{References}

Acheampong, Y. J., Epperson, J. E., Park, T. A., and Gunter, L. F. (2004) Globalization and profitability adjustment patterns in international food and consumer products industries, Department of Agricultural and Applied Economics Faculty Series 00-16, University of Georgia.

Akinola, G. O. (2012) Effect of globalization on performance in the Nigerian banking industry, International Journal of Management and Marketing Research, 5: 79-94.

Ardıç, N. (2009) Friend or foe? Globalization and Turkey at the turn of the 21 st century, Journal of Economic and Social Research, 11, 17-42.

Aseidu, E., and Freeman, J. A. (2007) The effect of globalization on the performance of smalland medium-sized enterprises in the United States: Does owners' race/ethnicity matter?, American Economic Review, 97(2), 368-372.

Besley, S., and Brigham, E. F. (2005) Essentials of managerial finance, 13th ed., Thomson South-Western: USA.

Choi, S. (2010) Beyond kantian liberalism: Peace through globalization, Conflict Management and Peace Science, 27, 272-295.

De, U. K., and Pal, M. (2011) Dimensions of globalization and their effects on economic growth and human development index, Asian Economic and Financial Review, 1(1), 1-13.

De Loecker, J., and Goldberg, P. K. (2014) Firm performance in a global market, Annual Review of Economics, 6(1), 201-227.

Dreher, A. (2006) Does globalization affect growth? Evidence from a new index of globalization, Applied Economics, 38: 1091-1110.

Dreher, A., and Gaston, N. (2007) Has globalization really had no effect on unions?, Kyklos, 60, 165-186.

Dreher, A., Gaston, N., and Martens, P. (2008) Measuring globalisation - Gauging its consequences, New York: Springer.

Donadelli, M., and Prosperi, L. (2012) The equity risk premium: empirical evidence from emerging markets, CASMEF Working Paper. 
Falope, O. I., and Ajilore, O. T. (2009) Working capital management and corporate profitability: evidence from panel data analysis of selected quoted companies in Nigeria, Research Journal of Business Management, 3, 73-84.

Garcia-Teruel, P. J., and Martinez-Solano, P. (2007) Effects of working capital management on SME profitability, International Journal of Managerial Finance, 3, 164-177.

Georgiou, M. N. (2011) Globalization and ROE: a panel data empirical analysis for Europe (1999-2009), SSRN Working Papers No: 1955200.

Giddens, A. (1990) Consequences of modernity, Cambridge: Polity Press.

Haghi, S., Mostafavi, S. M., and Behname, M. (2015) The effects of globalization on firm's stock in the selected Asian countries, Atlantic Review of Economics, 1, 1-13.

Hessami, Z. (2011) Globalization's winners and losers - Evidence from life satisfaction data 1975-2001, Economics Letters, 112(3), 250-253.

Hsu, M., and Chen, B. (2000) Labor productivity of small and large manufacturing firms: The case of Taiwan, Contemporary Economic Policy, 18(3), 270-83.

Kaplinsky, R. (2004) How does it all add up? Caught between a rock and a hard place, Paper submitted for the Globalization, Employment, and Economic Development Workshop, Sloan Workshop Series in Industry Studies, Rockport, Massachusetts, June, 14-16.

Karadagli, E. C. (2012) The effects of globalization on firm performance in emerging markets: Evidence from Emerging-7 Countries, Asian Economic and Financial Review, 2(7), 858865.

Karadagli, E. C. (2013) Globalization, firm performance and group affiliation in emerging markets: evidence from Turkey, in Financial Aspects of Recent Trends in the Global Economy, Mirdala, R. (Eds), I(8), 164-174.

Kefela, G. T. (2011) Driving forces of globalization in emerging market economies developing countries, Asian Economic and Financial Review, 1(2), 83-94.

Lamla, M. (2009) Long-run determinants of pollution: a robustness analysis, Ecological Economics, 69, 135-144.

Leibrecht, M., Klien, M., and Onaran, Ö. (2011) Globalization, welfare regimes and social protection expenditures in western and eastern European countries, Public Choice, 148: 569594.

Mahmutović, H., Talović, S., and Kurtović, S. (2017) Impact of globalization on the performance of the company: the case of companies from Bosnia and Herzegovina, Human, $7(1), 40-49$.

Padachi, K. (2006) Trends in working capital management and its impact on firms' performance: an analysis of Mauritian small manufacturing firms, International Review of Business Research Papers, 2(2), 45-58.

Peltonen, T. A., Skala, M., Santos Rivera, A., and Pula, G. (2008) Imports and profitability in the Euro area manufacturing sector. The role of emerging market economies, ECB Working Paper No 918 / July.

Rao, B. B., Tamazian, A., and Vadlamannati, K. C. (2011) Growth effects of a comprehensive measure of globalization with country specific time series data, Applied Economics, 43, 551568.

Scheuerman, W. (2010) Globalization, in The Stanford Encyclopedia of Philosophy (Sum. 2010 Ed.), Zalta, E. N., http://plato.stanford.edu/archives/sum2010/entries/globalization/

Szeman, I. (2003) Culture and globalization, or, the humanities in ruins, CR: The New Centennial Review, 3(2), 91-115.

Thoumrungroje, A., and Tansuhaj, P. (2007) Globalization effects and firm performance, Journal of International Business Research, 6(2), 43-58. 
Tomschik, D. (2015) The impact of macroeconomic variables on capital structure: a comparison between companies in E7 and G7 countries, Bachelor's thesis, University of Twente).

Tsai, M. (2007) Does globalization affect human well-being?, Social Indicators Research, 81, 103-126.

Vinig, T., and De Kluijver, J. (2007) Does globalization impact entrepreneurship? comparative study of country level indicators, Sprouts: Working Papers on Information Systems, 7(8), University of Amsterdam, Netherlands. 